\title{
Biochemical Evaluation of Phenylalanine Ammonia Lyase from Endemic Plant Cyathobasis fruticulosa (Bunge) Aellen. for the Dietary Treatment of Phenylketonuria
}

\author{
Seda Şirin ${ }^{1 *}$, Selcen Babaoğlu Aydaş² and Belma Aslım ${ }^{1}$ \\ ${ }^{1}$ Gazi University, Faculty of Science, Department of Biology, TR-06500 Teknikokullar, Ankara, Turkey \\ ${ }^{2}$ Gazi University, Vocational High School of Health Services, TR-06830 Gölbaşı, Ankara, Turkey
}

Received: November 2, 2015

Accepted: April 12, 2016

\begin{abstract}
Summary
Enzyme substitution therapy with the phenylalanine ammonia lyase (PAL) is a new approach to the treatment of patients with phenylketonuria (PKU). This enzyme is responsible for the conversion of phenylalanine to trans-cinnamic acid. We assessed the PAL enzyme of the endemic plant Cyathobasis fruticulosa (Bunge) Aellen. for its possible role in the dietary treatment of PKU. The enzyme was found to have a high activity of $(64.9 \pm 0.1) \mathrm{U} /$ $\mathrm{mg}$, with the optimum $\mathrm{pH}$, temperature and buffer (Tris- $\mathrm{HCl}$ and L-phenylalanine) concentration levels of $\mathrm{pH}=8.8,37^{\circ} \mathrm{C}$ and $100 \mathrm{mM}$, respectively. Optimum enzyme activity was achieved at $\mathrm{pH}=4.0$ and 7.5 , corresponding to $\mathrm{pH}$ levels of gastric and intestinal juice, and $\mathrm{NaCl}$ concentration of $200 \mathrm{mM}$. The purification of the enzyme by 1.87 -fold yielded an activity of $98.6 \mathrm{U} / \mathrm{mg}$. PAL activities determined by HPLC analyses before and after purification were similar. Two protein bands, one at 70 and the other at $23 \mathrm{kDa}$, were determined by Western blot analysis of the enzyme. This enzyme is a potential candidate for serial production of dietary food and biotechnological products.
\end{abstract}

Key words: Cyathobasis fruticulosa, endemic plant, enzyme purification, phenylalanine ammonia lyase (PAL), phenylketonuria (PKU)

\section{Introduction}

Phenylketonuria (PKU) is the most widely inherited disorder of amino acid metabolism, in which mutations affecting phenylalanine hydroxylase (PAH) lead to the inhibition of the hydroxylation of the essential amino acid phenylalanine (Phe) to tyrosine (1), leading to accumulation of the former in blood and tissues (2). Currently, the only way to prevent the disease from progressing and causing various sequelae is to adhere to a strict diet poor in Phe throughout the life of an individual, a task which is difficult and not entirely protective from the detrimental effects of low Phe levels (3). Hence there is a great demand for pharmacological approaches that can be used in the treatment of PKU today. One of them is alternative LNAA (large neutral amino acid) treatment, which aims to prevent Phe from entering into the brain and hopefully lower its cerebral amount by making LNAAs compete with Phe to cross blood-brain barrier (4).

Tetrahydrobiopterin $\left(\mathrm{BH}_{4}\right)$ acts as the cofactor of $\mathrm{PAH}$, mainly by increasing the residual PAH enzyme activity and stabilizing the enzyme tetramer in a multifactorial manner. Orally administered sapropterin dihydrochloride, a synthetic form of $\mathrm{BH}_{4}$, acts like $\mathrm{BH}_{4}$ in pharmacological doses in approx. one third of PKU patients (5). In recent years, studies on gene therapy using viral and other vectors have been conducted without any success due to difficulties in gene delivery and maintaining a stable expression. Plant phenylalanine ammonia lyase (PAL; EC 4.3.1.24) enzyme has been suggested as a new oral therapy for the treatment of PKU (6). 
PAL acts by transforming Phe into a metabolically inert substance called trans-cinnamic acid and trace amounts of ammonia. trans-Cinnamic acid is then converted to benzoic acid, which is renally excreted as hippurate. The enzyme does not use any cofactor (7). Although certain fungi and higher plants possess PAL activity, no animal has been shown to have this enzyme yet (8). Being one of several commercially available non-hydrolytic enzymes, plant PAL has been successfully utilized to treat certain neoplasms in mice as well as to measure serum levels of Phe in humans with PKU and diets low in Phe (9). Modest reductions in Phe levels have been attained in early trials of oral administration of PAL to humans. Some mouse models used a recombinant Anabaena variabilis PAL produced in Escherichia coli, which was subjected to genetic modification to achieve high protease resistance and conjugated with polyethylene glycol (PEG) to achieve a lower immunogenicity (rAvPAL-PEG) (10). Research efforts are ongoing to find ways to orally administer PAL or encapsulate the enzyme in red blood cells (5).

In the secondary metabolism of plants, PAL initiates the biochemical phenylpropanoid biosynthetic pathway, in which it is one of the most challenging enzymes (11). Its activity is increased by some physical and chemical factors such as light, salt, excision, fungal cell surface elicitors and phytohormones (12), and its levels and activity are expected to rise under stress. Enzymatic reaction produces cinnamic acid, which acts as a precursor of many secondary substances including lignins, flavonoid pigments, UV protectants, plant hormones and phytoalexins; it is also a major source of total carbon in plants $(13,14)$.

Cyathobasis fruticulosa (Bunge) Aellen. is a monotypic single species/single genus plant belonging to the genus Cyathobasis that is endemic to salt soils of Central Anatolia in Turkey. It is included in the tribe Salsoleae of the family Chenopodiaceae comprising a large variety of plants that contain alkaloids (15).

This study aims to evaluate the potential of a plant PAL enzyme to be used in biotechnology products for the treatment of PKU patients without any side effects. With high durability at environmental $\mathrm{pH}$ and temperature, and resistance to gastric and intestinal $\mathrm{pH}$ levels, these preparations may strengthen the effect of dietary therapies when added to the diet of PKU patients. They may also have a role as orally administered preparations. Another objective of this study is to report the endemic Cyathobasis fruticulosa (Bunge) Aellen. (Chenopodiaceae) as a natural product possessing a unique, high PAL activity.

\section{Materials and Methods}

\section{Plant material}

Cyathobasis fruticulosa naturally growing in fields rich in saline salts in Beypazarı, Ankara, Turkey, was collected in August 2011. The plant taxonomy was confirmed by Dr. Zeki Aytaç (Gazi University, Ankara, Turkey). A voucher specimen was deposited at the Herbarium of Gazi University, Ankara, Turkey (voucher ID: ZA-10439). The plants were stored at $-80^{\circ} \mathrm{C}$ until use.

\section{Extraction of PAL enzyme}

The leaves were weighed, frozen in liquid nitrogen, and ground in a mortar. The final pulverized powder was extracted in $50 \mathrm{mM}$ Tris (Sigma-Aldrich, Steinheim, Germany)- $\mathrm{HCl}$ (Merck, Darmstadt, Germany) buffer ( $\mathrm{pH}=8.8$ ) containing 10 mM 2- $\beta$-mercaptoethanol (Merck, Hohenbrunn, Germany), $1 \mathrm{mM}$ ethylenediaminetetraacetic acid (EDTA; Sigma-Aldrich) and $2.5 \%$ polyvinylpyrrolidone- 40 (PVP-40; Sigma-Aldrich). The mixture was centrifuged at $21180 \times g$ for $20 \mathrm{~min}$ and the clear supernatant was desalted in aliquots using an Amicon Ultra-15 Centrifugal Filter Units with a membrane nominal mass limit of $50 \mathrm{kDa}$ (Merck Millipore, Tullagreen Carrigtwohill, Ireland) and assayed for PAL activity under standard conditions. The aliquots were stored at $-20^{\circ} \mathrm{C}$ until use (16).

\section{PAL activity assay and biochemical property analysis}

Protein concentrations were determined by a dye-binding Bradford method using Bradford reagent (Sigma-Aldrich) and bovine serum albumin (Amresco, Cleveland, $\mathrm{OH}, \mathrm{USA}$ ) as the protein standard (17). PAL activity was assayed by measuring the trans-cinnamic acid formation at $290 \mathrm{~nm}$ using a UV-1800 UV-Vis spectrophotometer (Shimadzu, Kyoto, Japan) and calculated using a standard trans-cinnamic acid, $\geq 99 \%$ (Sigma-Aldrich) curve. The enzyme reaction mixture contained $100 \mathrm{mM}$ Tris- $\mathrm{HCl}, 40 \mathrm{mM}$ L-phenylalanine, $\geq 98 \%$ (Sigma-Aldrich), and an aliquot of the enzyme in a total volume of $1 \mathrm{~mL}$ at $\mathrm{pH}=8.8$. The reaction was carried out at $37^{\circ} \mathrm{C}$ for $30 \mathrm{~min}$ and terminated by the addition of $50 \mu \mathrm{L}$ of $4 \mathrm{M} \mathrm{HCl}$. PAL activity was expressed in $\mathrm{U} / \mathrm{mL}$ and PAL specific activity was expressed in $\mathrm{U} / \mathrm{mg}(16)$.

Determination of $\mathrm{pH}$, temperature and buffer concentration

To determine the optimum $\mathrm{pH}$, assays were performed at $37{ }^{\circ} \mathrm{C}$ for $30 \mathrm{~min}$ using a buffer (100 mM Tris$-\mathrm{HCl}$ and $40 \mathrm{mM}$ L-phenylalanine) with various $\mathrm{pH}$ values $(\mathrm{pH}=2.0-12.0)$. For optimum temperature determination, assays were performed at $\mathrm{pH}=8.8$ for $30 \mathrm{~min}$ at various temperatures $\left(10-70{ }^{\circ} \mathrm{C}\right)$. To determine the optimum buffer concentration, assays were performed at $37{ }^{\circ} \mathrm{C}$ and $\mathrm{pH}=8.8$ for $30 \mathrm{~min}$ using Tris- $\mathrm{HCl}$ buffer ( $40 \mathrm{mM}$ L-phenylalanine) and various concentrations (5-500 $\mathrm{mM}$ ) of Tris- $\mathrm{HCl}(18)$.

\section{Simulated gastric and intestinal digestion}

In vitro conditions simulating gastric and intestinal digestion were created. The reaction mixture was incubated with $3 \mathrm{~g} / \mathrm{L}$ of pepsin (Sigma-Aldrich), $\mathrm{pH}=2.0$ or 4.0 , for $30 \mathrm{~min}$ at $37^{\circ} \mathrm{C}$ to mimic the gastric phase. The reaction mixture was incubated with $1 \mathrm{~g} / \mathrm{L}$ of pancreatin (Sigma-Aldrich) and $0.30 \%$ bile salt (Difco, Franklin Lakes, NJ, USA), $\mathrm{pH}=5.5,7.5$ or 9.5 , for $30 \mathrm{~min}$ at $37^{\circ} \mathrm{C}$ to simulate the intestinal phase (19).

Determination of PAL specific activity under different $\mathrm{NaCl}$ concentrations

The PAL activity was determined in the presence of different concentrations (50-300 mM) of $\mathrm{NaCl}$ (Sigma-Al- 
drich, Hunterdon, NJ, USA) in the reaction mixture (9). Assays were performed at $37^{\circ} \mathrm{C}$ and $\mathrm{pH}=8.8$ for $30 \mathrm{~min}$ using $100 \mathrm{mM}$ Tris- $\mathrm{HCl}$ buffer and $40 \mathrm{mM}$ L-phenylalanine.

\section{Storage stability of PAL extract}

PAL extract was stored at either room temperature or at $4{ }^{\circ} \mathrm{C}$ for $1-5$ days and its activity was assayed. It was also stored at $-20^{\circ} \mathrm{C}$ for $1-12$ months and then its activity was determined. Assays were performed at $37^{\circ} \mathrm{C}$ and $\mathrm{pH}=8.8$ for $30 \mathrm{~min}$ using $100 \mathrm{mM}$ Tris- $\mathrm{HCl}$ buffer and 40 $\mathrm{mM}$ L-phenylalanine. The relative activity (in \%) of the extract was determined as a ratio of PAL specific activity in test conditions and PAL specific activity under optimum conditions ( $\mathrm{pH}=8.8,37^{\circ} \mathrm{C}$ and $100 \mathrm{mM}$ Tris- $\mathrm{HCl}$ ).

\section{HPLC separation of PAL}

The concentration of trans-cinnamic acid (PAL product) formed was determined using different volumes of PAL enzyme (100-300 $\mu \mathrm{L})$, different concentrations of substrate $(40-160 \mathrm{mmol} / \mathrm{L})$ and different reaction times (30-90 $\mathrm{min}$ ). The percentage of conversion of L-phenylalanine to trans-cinnamic acid was also determined under the following conditions: $300 \mu \mathrm{L}$ of enzyme, $160 \mathrm{mmol} / \mathrm{L}$ of substrate and reaction time $60 \mathrm{~min}$. The HPLC separation of the sample components was achieved both before and after the enzyme purification. trans-Cinnamic acid detection was performed on an Agilent Technologies HPLC 1200 series (Santa Clara, CA, USA) equipped with a quaternary pump, a manual sampler and an ultraviolet/ visible (UV-Vis) detector. The column used was a $5 \mu \mathrm{m} \mathrm{C}_{18}$ (250 mm $\times 4.6 \mathrm{~mm}$ i.d.) from Advanced Chromatography Technologies (ACE, Aberdeen, Scotland, UK). The column was operated at $25{ }^{\circ} \mathrm{C}$. The mobile phase consisted of $35 \% \mathrm{H}_{2} \mathrm{O}$ acetic acid and $65 \%$ methanol (both from Merck, Darmstadt, Germany). The injection volume of all samples was $20 \mu \mathrm{L}$. Simultaneous monitoring was performed at $280 \mathrm{~nm}$ and a flow rate of $1 \mathrm{~mL} / \mathrm{min}(20)$.

\section{Partial purification of PAL}

The enzyme was partially purified in a two-step procedure involving ammonium sulfate (Merck, Darmstadt) precipitation and dialysis $(21,22)$. The enzyme extract was brought to $60 \%$ saturation by gradual addition of solid ammonium sulfate while stirring at $4{ }^{\circ} \mathrm{C}$. After $20 \mathrm{~min}$ of equilibration, the precipitated protein was obtained by centrifugation at $10000 \times g$ at $4{ }^{\circ} \mathrm{C}$ for $30 \mathrm{~min}$. The pellet was resuspended in $100 \mathrm{mM}$ ice-cold Tris- $\mathrm{HCl}(\mathrm{pH}=8.8)$. Enzyme activity and protein content were determined after separation of each fraction. The pretreated Slide-A-Lyzer ${ }^{\mathrm{TM}}$ G2 Dialysis Cassettes, molecular mass cut-off of 20000 (Thermo Fisher Scientific, Rockford, IL, USA), were used for dialysis of the enzyme collected and suspended after ammonium sulfate precipitation. The enzyme was dialyzed against $100 \mathrm{mM}$ Tris- $\mathrm{HCl}(\mathrm{pH}=8.8)$ at $4{ }^{\circ} \mathrm{C}$ for 1-2 $\mathrm{h}$. The buffer was changed, and the enzyme was dialyzed for an additional 1-2 $\mathrm{h}$. In the last step, dialysis was continued overnight at $4{ }^{\circ} \mathrm{C}$ in $100 \mathrm{mM}$ Tris- $\mathrm{HCl}(\mathrm{pH}=8.8)$ reaction buffer (more than 200-fold of the sample volume). The dialysate was centrifuged at $21180 \times g$ for $20 \mathrm{~min}$ using an Amicon Ultra-15 Centrifugal Filter Unit (Merck Millipore). The partially purified sample was assayed for protein content and enzyme activity.

\section{SDS-PAGE of PAL}

Sodium dodecyl sulfate-polyacrylamide gel electrophoresis (SDS-PAGE) gels containing 4-10\% acrylamide (Merck, Hohenbrunn) were used and stained with Coomassie Brilliant Blue R-250 (Sigma-Aldrich) to visualize the PAL protein. The stacking gel (4\%) consisted of: 29.2 $\%$ acrylamide and $8 \% N, N^{\prime}$-methylene-bis-acrylamide (Sigma-Aldrich), 1.5 M Tris- $\mathrm{HCl}$ ( $\mathrm{pH}=8.8), 10 \%$ sodium dodecyl sulfate (SDS; Sigma-Aldrich), $10 \%$ ammonium persulfate (APS; Sigma-Aldrich), $N, N, N^{\prime}, N^{\prime}$-tetramethylethylenediamine (TEMED; Sigma-Aldrich) and the separating gel $(10 \%)$ consisted of: $30 \%$ acrylamide- $N, N^{\prime}$ methylene-bis-acrylamide, $0.5 \mathrm{M}$ Tris- $\mathrm{HCl}(\mathrm{pH}=6.8), 10 \%$ SDS, $10 \%$ APS and TEMED. PageRuler ${ }^{\mathrm{TM}}$ Prestained Protein Ladder (10 to $170 \mathrm{kDa}$; Thermo Fisher Scientific, Vilnius, Lithuania) was used as a size standard (23).

\section{Electrophoresis and Western blotting}

SDS-PAGE was performed on 4-12\% Bis-Tris gels $\left(\mathrm{NuPAGE}^{\circledR}\right.$; Thermo Fisher Scientific, Canoga Park, CA, USA) using a mini-cell gel system (XCell SureLock ${ }^{\mathrm{TM}}$; Invitrogen, Carlsbad, CA, USA). Following electrophoresis, proteins were stained with Coomassie Brilliant Blue R-250 and destained with dye-destaining solution. After separation, the proteins were transferred onto a polyvinylidine difluoride (PVDF) membrane $\left(0.2 \mu \mathrm{m}\right.$ pore size; $\left.\mathrm{NuPAGE}^{\circledR}\right)$ using an iBlot $^{\circledR}$ device $(120 \mathrm{~V}, 1 \mathrm{~h}$, room temperature; Invitrogen). All subsequent steps were carried out with a WesternBreeze $^{\circledast}$ kit (Invitrogen) according to the manufacturer's instructions. The kit contained blocking solution, the primary antibody diluents, secondary antibody (anti-rabbit) diluents, chromogenic substrate and washing solutions. The membrane was blocked for $30 \mathrm{~min}$ in the concentrated saline buffer solution containing detergent and the Hammerstein casein solution, then incubated for $1 \mathrm{~h}$ with primary polyclonal PAL antibody (Tübitak MAM, Gebze, Kocaeli, Turkey), washed with the concentrated saline buffer solution and incubated for $30 \mathrm{~min}$ with alkaline phosphatase-conjugated anti-rabbit IgG antibody. The excess of the secondary antibody was washed away three times and incubation continued with the 5-bromo-4-chloro-3'-indolyphosphate $p$-toluidine salt (BCIP) and nitroblue tetrazolium chloride (NBT) substrate solution for determination of alkaline phosphatase until purple bands developed on the membrane. The colour development was completed in 1 to $60 \mathrm{~min}$. The membrane was rinsed twice with double distilled $\mathrm{H}_{2} \mathrm{O}$ for $2 \mathrm{~min}$ and dried. The chromogenic band was visualized with UVP BioSpectrum 410 (Upland, CA, USA) imaging system $(24,25)$.

\section{Statistical analysis}

All experiments were performed three times, and the mean value of each measurement was calculated. All results were reported as mean value \pm standard deviation (S.D.). 


\section{Results and Discussion}

Enzyme therapy with phenylalanine ammonia lyase (PAL) is complicated because it requires large amounts of purified, highly specific PAL and the activation of immune system with resultant immunological reaction against plant PAL. As such, repeated PAL administration leads to antibody production against it, resulting in both rapidly vanishing serum PAL activity and potentially detrimental allergic reactions. It was reported that in order to maintain therapeutic efficacy, PAL enzyme should stay in blood for an extended period (26). This issue has been formerly addressed by multitubular enzyme reactors with immobilized PAL (from Rhodotorula glutinis), which enabled to remove $77 \%$ of blood phenylalanine (Phe) rapidly, without the enzyme entering circulation (27). Novel plant PALs displaying unique properties are still being actively sought.

The PAL activity of Cyathobasis fruticulosa is reportedly higher $((64.9 \pm 0.1) \mathrm{U} / \mathrm{mg})$ than those of other plants, including Bambusa oldhamii with a PAL activity of $0.19 \mathrm{U} / \mathrm{mg}$ (25), Fragaria $\times$ ananassa $44.5 \mathrm{U} / \mathrm{mg}$ (28), Cucurbita pepo 26.6 $\mathrm{U} / \mathrm{mg}(9)$, and Glycine max $0.43 \mathrm{U} / \mathrm{mg}$ (29). Plants are able to utilize light, carbon dioxide and various inorganic substances in an efficient manner for their relatively simple vital demands. Hence, they produce a variety of important therapeutic substances for humans. Mass cultivation allows some plants with high nutritional potential and nonpathogenic composition to be grown in huge amounts as part of commercial production (30). Hence, plants could also be a very valuable commercial source of PAL enzyme; however, this enzyme should be further optimized for use in human body.

PAL enzyme derived from $C$. fruticulosa has a specific activity of (54.9 \pm 0.1$) \mathrm{U} / \mathrm{mg}$ at its optimum $\mathrm{pH}=8.8$. A similar $\mathrm{pH}$ range of 7.5-10.6 was also reported for PAL from other plants such as Ustilago maydis (31), Nicotiana tabacum (32), Hordeum vulgare and Medicago sativa (33). Our study demonstrated a significantly lower enzymatic activity (Fig. 1a) in acidic medium ( $\mathrm{pH}=2.0,(45.3 \pm 0.0) \mathrm{U} / \mathrm{mg}$ ), while enzymatic activity was improved at a slightly alkaline $\mathrm{pH}$ and it was still present at $\mathrm{pH}=12((50.4 \pm 0.0) \mathrm{U} / \mathrm{mg})$. Hence, it was concluded that isolated C. fruticulosa PAL is an alkaline enzyme. The enzyme lost its activity at $60{ }^{\circ} \mathrm{C}$ or above, and had activities of $(44.5 \pm 0.1)$ and $(40.9 \pm 0.1) \mathrm{U} / \mathrm{mg}$ at 10 and $50{ }^{\circ} \mathrm{C}$, respectively. Its optimum temperature was $37^{\circ} \mathrm{C}$ with the activity of $(54.9 \pm 0.1) \mathrm{U} / \mathrm{mg}$ (Fig. 1b). Previous reports have indicated a temperature range of 25 to $60^{\circ} \mathrm{C}$ for other PAL enzymes derived from Musa sp. (34), Triticum aestivum (19), Ephedra sinica (35) and Vitis vinifera (36). Activities of $(39.1 \pm 0.1)$ and $(44.6 \pm 0.1) \mathrm{U} / \mathrm{mg}$ were recorded at 5 and $500 \mathrm{mM}$ buffer concentrations, respectively. PAL enzyme derived from $C$. fruticulosa had an optimum buffer concentration of $100 \mathrm{mM}$ Tris- $\mathrm{HCl}$

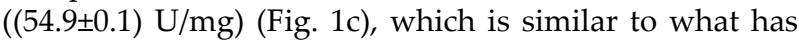
been reported for other plant PAL enzymes, including those of Cucurbita pepo (9), Medicago sativa (21) and Glycine $\max (29)$.

The enzyme is susceptible to degradation by gastrointestinal proteases when orally administered, necessitating the advancement of novel ways to protect it from enzymatic proteolysis or acidic denaturation and to bring it into contact with enteric Phe (19). Gastric $\mathrm{pH}$ has a range between 1.5 and 2, and intestinal $\mathrm{pH}$ between 6 and 7.5, depending on dietary factors (37). As Phe enters enterocirculation, enzyme development efforts should give priority to oral formulations containing entrapped PAL, which enable the release of Phe from bloodstream into the gastrointestinal tract where it is metabolized but not reabsorbed (38). We therefore measured PAL activity of $C$. fruticulosa in artificial gastric and intestinal fluids. The relative activity was not different between $\mathrm{pH}=2.0$ and 4.0 in the simulated gastric phase and $\mathrm{pH}=5.5,7.5$ and 9.5 in the simulated intestinal phase (Fig. 2a). In a previous report, PAL of permeabilized R. glutinis cells was completely inactivated by proteases found in duodenal juice within 30 min (39); thus, our results indicated a more favourable stability of enzyme activity.
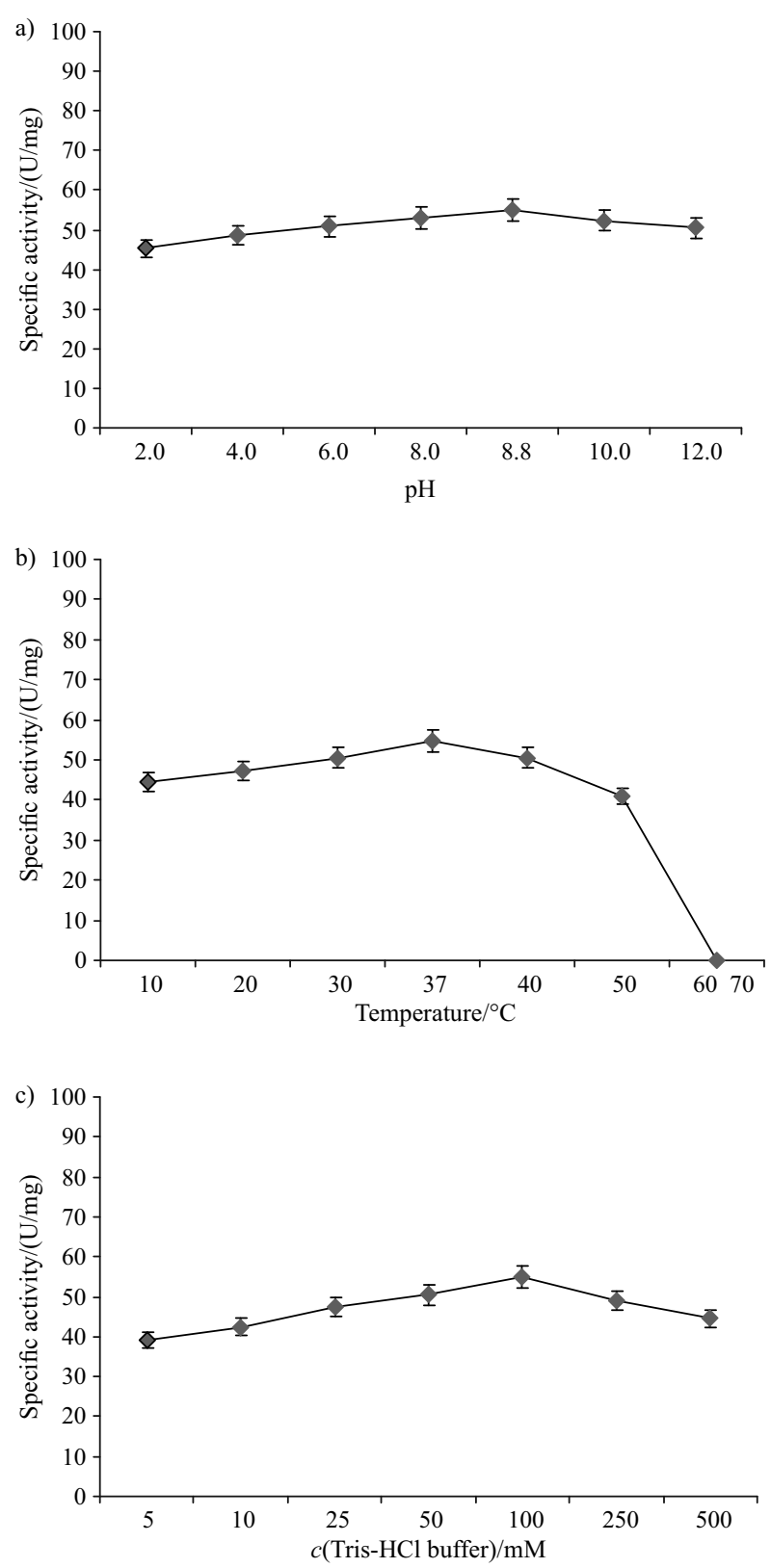

Fig. 1. Effect of: a) $\mathrm{pH}, \mathrm{b}$ ) temperature and c) Tris- $\mathrm{HCl}$ buffer concentration on phenylalanine ammonia lyase (PAL) activity 
Above optimal concentrations, $\mathrm{NaCl}$ may give rise to hysteresis followed by reduction of the enzymatic activity. Shielding of negatively charged amino acid residues and increasing hydrophobic interactions within the protein molecule are responsible for the stability of proteins (9). Thus, various $\mathrm{NaCl}$ concentrations were studied for their impact on PAL activity of $C$. fruticulosa at a $\mathrm{pH}=8.8$ (Fig. 2b). According to this analysis, the optimum $\mathrm{NaCl}$ concentration was determined to be $200 \mathrm{mM}$, similar to what was reported by Guo and Wang (40) and El-Shora (9). As $\mathrm{NaCl}$ concentration was increased to a range of 250-300 mM, the relative activity was reduced (Fig. 2b).
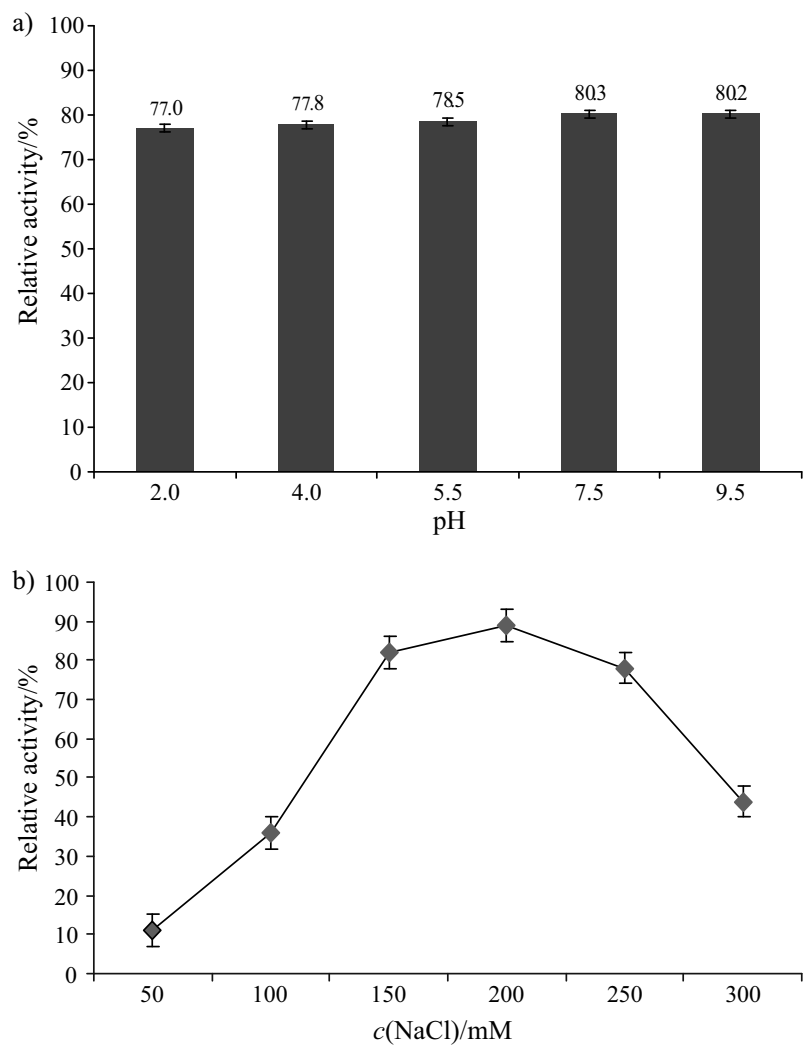

Fig. 2. Effect of: a) simulating gastric $\mathrm{pH}(2$ and 4$)$ and intestinal phase $\mathrm{pH}(5.5,7.5$ and 9.5), and b) $\mathrm{NaCl}$ concentration in the reaction mixture on phenylalanine ammonia lyase (PAL) activity

Enzyme denaturation and reaction rates are altered by storage temperature. As shown in Fig. 3, enzyme activity of $C$. fruticulosa PAL was absent at $4{ }^{\circ} \mathrm{C}$ whereas it was stable at $-20{ }^{\circ} \mathrm{C}$ and maintained so for 12 months. This result was in contrast to several reports that reported a $38 \%$ loss in enzyme activity in 3 months at $-20{ }^{\circ} \mathrm{C}(19)$, an almost $100 \%$ loss in 7 days at $6{ }^{\circ} \mathrm{C}(29)$, and a $25 \%$ loss in 3.5 months at $-10^{\circ} \mathrm{C}(33)$.

The amount of formed trans-cinnamic acid was also determined by HPLC to measure the activity of $C$. fruticulosa PAL. A range of concentrations of $40-160 \mathrm{mmol} / \mathrm{L}$ produced mass concentrations of trans-cinnamic acid ranging between 3.3 and $3.7 \mathrm{ng} / \mathrm{mL}$. A 90-minute reaction time and a volume of enzyme of $300 \mu \mathrm{L}$ produced the greatest mass concentrations of trans-cinnamic acid (6.2 and 8.4 $\mathrm{ng} / \mathrm{mL}$, respectively) determined by HPLC (Fig. 4).
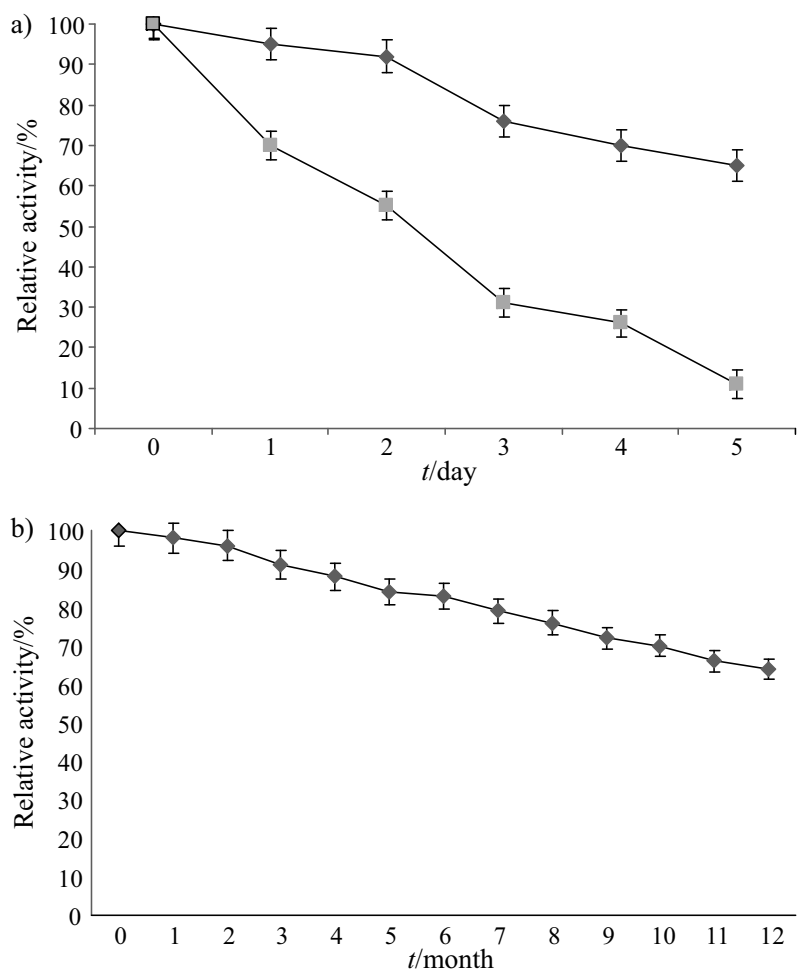

Fig. 3. The storage stability of phenylalanine ammonia lyase (PAL) at: a) room temperature $(\square)$ and $4{ }^{\circ} \mathrm{C}(\diamond)$, and b) at $-20^{\circ} \mathrm{C}$

Pre-purification results showed that before and after enzymatic reaction, the $\mathrm{L}$-phenylalanine was detected at concentrations of $(160.0 \pm 2.3)$ and $(124.0 \pm 1.8) \mathrm{mmol} / \mathrm{L}$, respectively, which corresponded to the conversion rate of L-phenylalanine to trans-cinnamic acid of $(22.5 \pm 1.3) \%$ and a post-reaction trans-cinnamic acid mass concentration of $(12.3 \pm 1.0) \mathrm{ng} / \mathrm{mL}$. Chromatographic separation of the reaction mixture was completed within less than 10 min. L-Phenylalanine and trans-cinnamic acid had retention times of 2.7 and $5.6 \mathrm{~min}$, respectively (Fig. 5).

Purification yield of $C$. fruticulosa PAL from crude extract was 1.87 -fold, which is lower than that of Medicago sativa (21). The final specific activity of $C$. fruticulosa was 98. $6 \mathrm{U} / \mathrm{mg}$ (Table 1), while lower values have been previously obtained for other species such as Cucurbita pepo (26.60 U/mg; 9) and Oryza sativa (4.625 nkat/mg; 41). SDS-PAGE of partially purified PAL produces a single protein band corresponding to a molecular mass $(M)$ of about 70 $\mathrm{kDa}$ (Fig. 6). Other values of molecular masses were 80 kDa for Bambusa oldhamii reported by Hsieh et al. (25) and $84 \mathrm{kDa}$ for Oryza sativa reported by Sarma and Sharma (41).

The trans-cinnamic acid mass concentration yielded by the partially purified $C$. fruticulosa PAL was measured with HPLC. A substrate concentration of 40-160 mmol/L yielded a trans-cinnamic acid mass concentration of 3.1$3.3 \mathrm{ng} / \mathrm{mL}$. A 90-minute reaction time and an enzyme volume of $300 \mu \mathrm{L}$ yielded the highest trans-cinnamic acid concentration (6.9 ng/mL) (Fig. 4).

After partial purification, L-phenylalanine was detected at concentrations of $(160.0 \pm 2.6)$ and $(122.0 \pm 2.2) \mathrm{mmol} / \mathrm{L}$ before and after the enzymatic reaction, respectively, which 

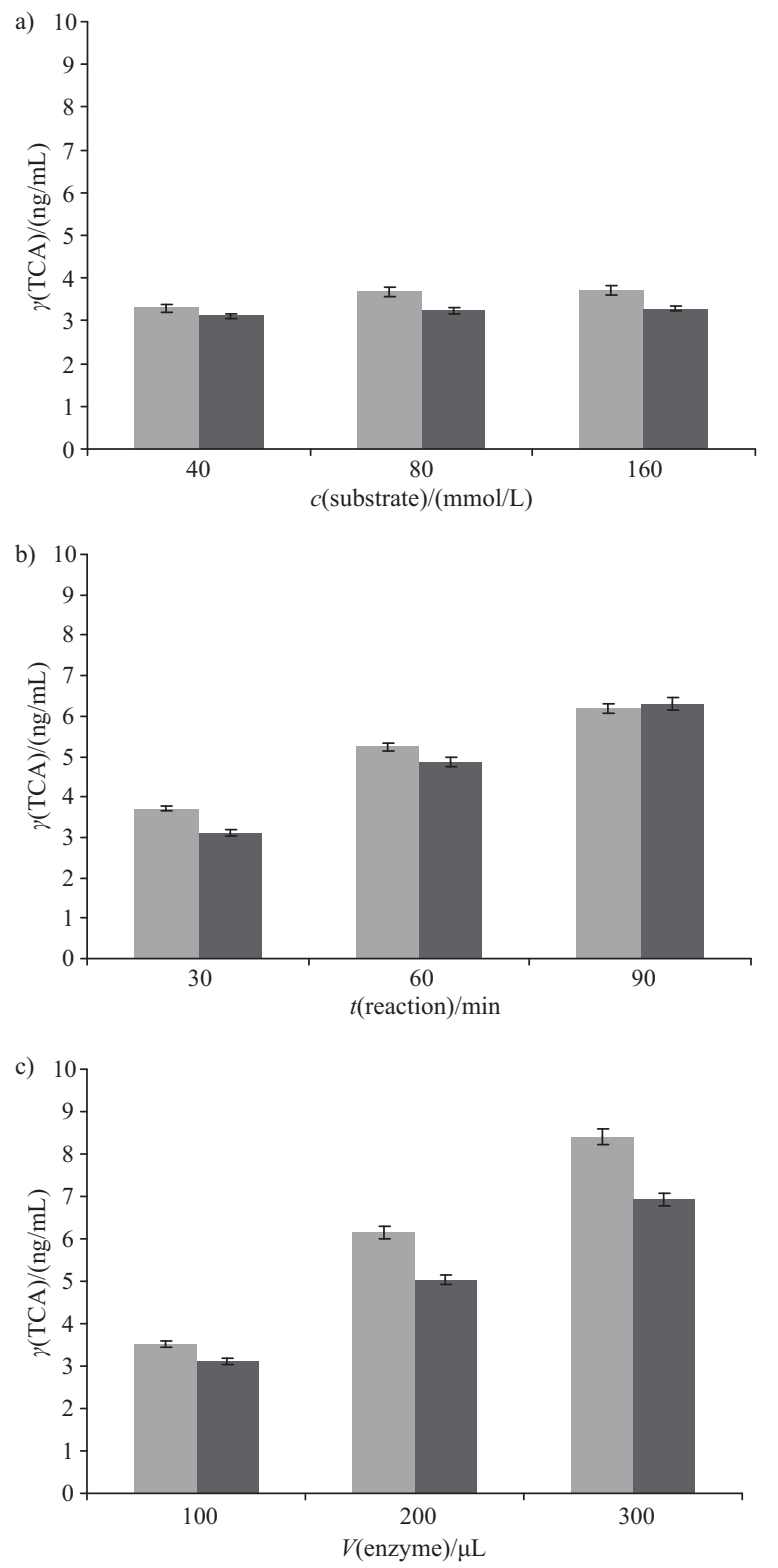

Fig. 4. Effect of: a) substrate concentration, b) reaction time, and c) enzyme volume on mass concentration of trans-cinnamic acid (TCA)
Table 1. Partial purification of phenylalanine ammonia lyase (PAL) from Cyathobasis fruticulosa

\begin{tabular}{|c|c|c|c|c|c|}
\hline \multirow{2}{*}{$\begin{array}{l}\text { Purification } \\
\text { step }\end{array}$} & $\begin{array}{c}m \text { (total } \\
\text { protein) }\end{array}$ & $\begin{array}{c}\text { Total } \\
\text { activity }\end{array}$ & $\begin{array}{l}\text { Specific } \\
\text { activity }\end{array}$ & $\begin{array}{l}\text { Purifi- } \\
\text { cation }\end{array}$ & $Y$ \\
\hline & $\mathrm{mg}$ & $\mathrm{U} / \mathrm{mL}$ & $\mathrm{U} / \mathrm{mg}$ & fold & $\overline{\%}$ \\
\hline Crude extract & $0.8 \pm 0.0$ & $40.8 \pm 0.0$ & $52.6 \pm 0.1$ & 1 & 100 \\
\hline $\begin{array}{l}\left(\mathrm{NH}_{4}\right)_{2} \mathrm{SO}_{4} \\
\text { precipitation }\end{array}$ & $0.6 \pm 0.0$ & $40.2 \pm 0.0$ & $63.4 \pm 0.1$ & 1.21 & 98.7 \\
\hline Dialysis & $0.4 \pm 0.0$ & $39.8 \pm 0.0$ & $98.6 \pm 0.2$ & 1.87 & 97.6 \\
\hline
\end{tabular}

is equal to the L-phenylalanine to trans-cinnamic acid conversion rate of $(23.8 \pm 1.5) \%$ and a post-reaction trans-cinnamic acid mass concentration of $(13.0 \pm 1.2) \mathrm{ng} / \mathrm{mL}$. Chromatographic separation of the reaction mixture was completed within less than $10 \mathrm{~min}$, with the retention times of L-phenylalanine and trans-cinnamic of 2.7 and 5.6 min, respectively (Fig. 5). Pre- and post-purification PAL activities measured by HPLC were in accordance with each other.

Western blot analysis of $C$. fruticulosa PAL was done by SDS-PAGE. The blotted protein extracts of $C$. fruticulosa were probed by anti-rabbit PAL antibodies, and a major band was spotted in the region corresponding to the molar mass $(M)$ of the $C$. fruticulosa PAL subunit of 70 $\mathrm{kDa}$, as well as a minor band in the region corresponding to the $M$ of the $C$. fruticulosa PAL subunit of $23 \mathrm{kDa}$ (Fig. 6).

Plants possess PAL activity that is regulated by a variety of PAL-encoding genes which may be uniquely encoded only in some regions of plants or under certain environmental conditions (9). It has formerly been shown that various plants contain PAL enzymes with a heterotetramer structure (42). For instance, PAL from Rhizoctonia solani has an $\alpha$-chain of $70 \mathrm{kDa}$ and a $\beta$-chain of $90 \mathrm{kDa}$ (43), while that from Triticum aestivum possesses a heterotetramer structure with an $\alpha$-chain of $75 \mathrm{kDa}$ and a $\beta$-chain of $80 \mathrm{kDa}(29)$. We also detected a minor band corresponding to a $M \approx 23 \mathrm{kDa}$, suggesting that the $C$. fruticulosa PAL enzyme also possesses a heterotetramer structure. A protein analysis will accurately establish such a structure.

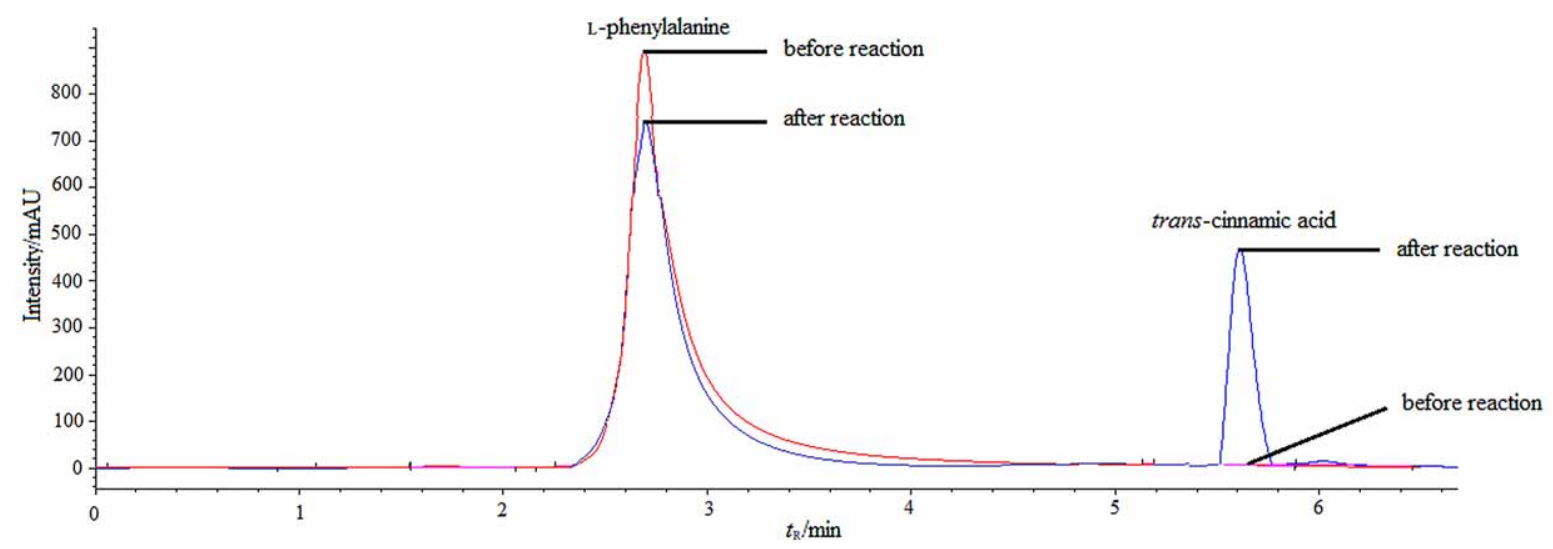

Fig. 5. Comparison of L-phenylalanine and trans-cinnamic acid amounts before and after enzymatic reaction, as a result of phenylalanine ammonia lyase (PAL) activity as determined by HPLC 


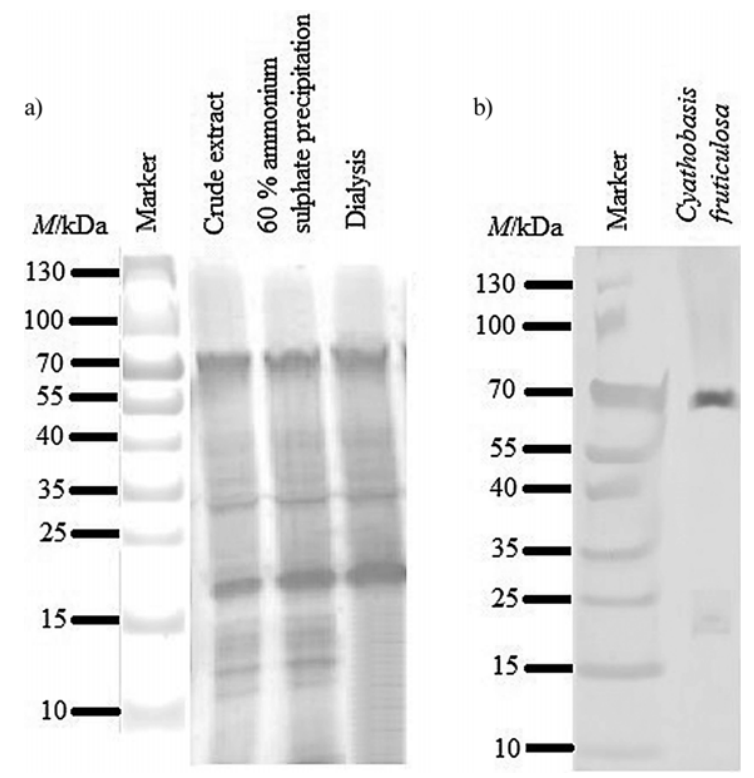

Fig. 6. SDS-PAGE of phenylalanine ammonia lyase (PAL) at various stages of partial purification (a) and Western blot of PAL from Cyathobasis fruticulosa (b)

\section{Conclusion}

Blood phenylalanine (Phe) level of phenylketonuria (PKU) patients should be adequately lowered to non-toxic concentrations by early initiated, strict dietary measures, which effectively averts neurological and functional sequelae, although this measure does not usually suffice alone to keep Phe levels low for a lifetime. Hence, search for alternative therapies for PKU patients is ongoing, such as large neutral amino acids (LNAA), sapropterin, gene therapy, phenylalanine ammonia lyase (PAL), and others. Replacement of the culprit enzyme is an attractive solution, but the relationship between repeated dosage, immunogenicity, and treatment efficacy should be meticulously studied before the administration of the enzyme in humans. As a candidate enzyme, PAL derived from Cyathobasis fruticulosa has a high activity that is not lost under a variety of physical and chemical conditions such as differing $\mathrm{pH}$, temperature, and $\mathrm{NaCl}$ concentration. The advantage of the enzyme in question is that it is stable at body temperature (i.e. $37^{\circ} \mathrm{C}$ ) and immune to degradation by artificial gastric juices and intestinal fluids. Hence, it appears that it would be a useful candidate for mass production of dietary products by food industry and of biotechnological products by pharmaceutical companies that develop treatments for PKU patients.

\section{Funding}

This study was part of a project (Project No 46/2011-03) funded by Gazi University, Turkey. The authors declare that they have no conflict of interest.

\section{References}

1. Qi Y, Mould DR, Zhou H, Merilainen M, Musson DG. A prospective population pharmacokinetic analysis of sapropterin dihydrochloride in infants and young children with phenylketonuria. Clin Pharmacokinet. 2015;54:195-207. http://dx.doi.org/10.1007/s40262-014-0196-4

2. van Spronsen FJ. Phenylketonuria: a 21st century perspective. Nat Rev Endocrinol. 2010;6:509-14. http://dx.doi.org/10.1038/nrendo.2010.125

3. van Calcar S. Phenylketonuria: the diet basics. In: Bernstein LE, Rohr F, Helm JR, editors. Nutrition management of inherited metabolic diseases: lessons from metabolic university. Cham, Switzerland: Springer International Publishing AG; 2015. pp. 101-16.

http://dx.doi.org/10.1007/978-3-319-14621-8_10

4. Pardridge WM. Blood-brain barrier amino-acid transport: clinical implications. In: Cockburn F, Gitzelmenn R, editors. Inborn errors of metabolism in humans. Lancaster, UK: MTP Press Limited; 1982. pp. 87-99.

http://dx.doi.org/10.1007/978-94-009-7325-1_6

5. Blau N, Longo N. Alternative therapies to address the unmet medical needs of patients with phenylketonuria. Expert Opin Pharmacother. 2015;16:791-800. http://dx.doi.org/10.1517/14656566.2015.1013030

6. Shah RM, D'Mello AP. Stabilization of phenylalanine ammonia lyase against organic solvent mediated deactivation. Int J Pharm. 2007;331:107-15. http://dx.doi.org/10.1016/j.ijpharm.2006.11.044

7. Sarkissian CN, Shao Z, Blain F, Peevers R, Su H, Heft R, et al. A different approach to treatment of phenylketonuria: phenylalanine degradation with recombinant phenylalanine ammonia lyase. Proc Natl Acad Sci USA. 1999;96:2339-44. http://dx.doi.org/10.1073/pnas.96.5.2339

8. Rösler J, Krekel F, Amrhein N, Schmid J. Maize phenylalanine ammonia-lyase has tyrosine ammonia-lyase activity. Plant Physiol. 1997;113:175-9. http://dx.doi.org/10.1104/pp.113.1.175

9. El-Shora HM. Properties of phenylalanine ammonia-lyase from marrow cotyledons. Plant Sci. 2002;162:1-7. http://dx.doi.org/10.1016/S0168-9452(01)00471-X

10. Sarkissian CN, Gámez A, Wang L, Charbonneau M, Fitzpatrick P, Lemontt JF, et al. Preclinical evaluation of multiple species of PEGylated recombinant phenylalanine ammonia lyase for the treatment of phenylketonuria. Proc Natl Acad Sci USA. 2008;105:20894-9. http://dx.doi.org/10.1073/pnas.0808421105

11. Ohl S, Hedrick SA, Chory J, Lamb CJ. Functional properties of a phenylalanine ammonia-lyase promoter from Arabidopsis. Plant Cell. 1990;2:837-48.

http://dx.doi.org/10.1105/tpc.2.9.837

12. Bolwell GP, Bell JN, Cramer CL, Schuch W, Lamb CJ, Dixon RA. L-Phenylalanine ammonia-lyase from Phaseolus vulgaris: characterisation and differential induction of multiple forms from elicitor-treated cell suspension cultures. Eur J Biochem. 1985;149:411-9. http://dx.doi.org/10.1111/j.1432-1033.1985.tb08941.x

13. Smith-Becker J, Marois E, Huguset EJ, Midland SL, Sims JJ, Keen NT. Accumulation of salicylic acid and 4-hydroxybenzoic acid in phloem fluids of cucumber during systemic acquired resistance is preceded by a transient increase in PAL activity in petiole and stems. Plant Physiol. 1998;116:231-8. http://dx.doi.org/10.1104/pp.116.1.231

14. Chen M, McClure JW. Altered lignin composition in phenylalanine ammonia-lyase inhibited radish seedlings: implication for seed-derived sinapoyl esters as lignin precursors. Phytochemistry. 2000;53:365-70. http://dx.doi.org/10.1016/S0031-9422(99)00531-2

15. Küçükosmanoğlu Bahçeevli A, Kurucu S, Kolak U, Topçu G, Adou E, Kingston DGI. Alkaloids and aromatics of Cyathobasis fruticulosa (Bunge) Aellen. J Nat Prod. 2005;68:956-8. http://dx.doi.org/10.1021/np0580006 
16. Goldson A, Lam M, Scaman CH, Clemens S, Kermode A. Screening of phenylalanine ammonia lyase in plant tissues and retention of activity during dehydration. J Sci Food Agric. 2008;88:619-25. http://dx.doi.org/10.1002/jsfa.3126

17. Bradford MM. Rapid and sensitive method for the quantitation of microgram quantities of protein utilizing the principle of protein-dye binding. Anal Biochem. 1976;72:248-54. http://dx.doi.org/10.1016/0003-2697(76)90527-3

18. D'Cunha GB. Enrichment of phenylalanine ammonia lyase activity of Rhodotorula yeast. Enzyme Microb Tech. 2005;36: 498-502.

http://dx.doi.org/10.1016/j.enzmictec.2004.11.006

19. Lam M, Scaman $\mathrm{CH}$, Clemens S, Kermode A. Retention of phenylalanine ammonia-lyase activity in wheat seedlings during storage and in vitro digestion. J Agric Food Chem. 2008;56:11407-12.

http://dx.doi.org/10.1021/jf8021942

20. Spierto FW, Whitfield W, Apetz M, Hannon WH. Liquidchromatographic measurement of phenylalanine and tyrosine in serum. Clin Chem. 1982;28:2282-5.

21. Jorrin J, Dixon RA. Stress responses in alfalfa (Medicago sativa L.) II. Purification, characterization, and induction of phenylalanine ammonia-lyase isoforms from elicitor-treated cell suspension cultures. Plant Physiol. 1990;92:447-55. http://dx.doi.org/10.1104/pp.92.2.447

22. Whetten RW, Sederoff RR. Phenylalanine ammonia-lyase from loblolly pine purification of the enzyme and isolation of complementary DNA clones. Plant Physiol. 1992;98:380-6. http://dx.doi.org/10.1104/pp.98.1.380

23. Lim HW, Park SS, Lim CJ. Purification and properties of phenylalanine ammonia-lyase from leaf mustard. Mol Cells. 1997; 7:715-20.

24. Noda S, Miyazaki T, Miyoshi T, Miyake M, Okai N, Tanaka T, et al. Cinnamic acid production using Streptomyces lividans expressing phenylalanine ammonia lyase. J Ind Microbiol Biotechnol. 2011;38:643-8. http://dx.doi.org/10.1007/s10295-011-0955-2

25. Hsieh LS, Hsieh YL, Yeh CS, Cheng CY, Yang CC, Lee PD. Molecular characterization of a phenylalanine ammonia-lyase gene (BoPAL1) from Bambusa oldhamii. Mol Biol Rep. 2011;38:283-90.

http://dx.doi.org/10.1007/s11033-010-0106-2

26. Ikeda K, Schiltz E, Fujii T, Takahashi M, Mitsui K, Kodera Y, et al. Phenylalanine ammonia-lyase modified with polyethylene glycol: potential therapeutic agent for phenylketonuria. Amino Acids. 2005;29:283-7. http://dx.doi.org/10.1007/s00726-005-0218-5

27. Ambrus CM, Anthone S, Horvath C, Kalghathi K, Lele AS, Eapen $\mathrm{G}$, et al. Extracorporeal enzyme reactors for depletion of phenylalanine in phenylketonuria. Ann Intern Med. 1987; 106:531-7. http://doi.org/10.7326/0003-4819-106-4-531

28. Cao S, Hu Z, Zheng Y, Lu B. Effect of BTH on anthocyanin content and activities of related enzymes in strawberry after harvest. J Agric Food Chem. 2010;58:5801-5. http://dx.doi.org/10.1021/jf100742v

29. Havir EA. Phenylalanine ammonia-lyase: purification and characterization from soybean cell suspension cultures. Arch
Biochem Biophys. 1981;211:556-63.

http://dx.doi.org/10.1016/0003-9861(81)90490-2

30. Deng MD, Coleman JR. Ethanol synthesis by genetic engineering in Cyanobacteria. Appl Environ Microbiol. 1999;65: 523-8.

31. Kim SH, Kronstad JW, Ellis BE. Purification and characterization of phenylalanine ammonia-lyase from Ustilago maydis. Phytochemistry. 1996;43:351-7. http://dx.doi.org/10.1016/0031-9422(96)00282-8

32. Nagai N, Kojima Y, Shimosaka M, Okazaki M. Effects of kinetin on L-phenylalanine ammonia-lyase activity in tobacco cell culture. Agr Biol Chem. 1988;52:2617-9. http://dx.doi.org/10.1080/00021369.1988.10869090

33. Koukol J, Conn EE. The metabolism of aromatic compounds in higher plants. IV. Purification and properties of the phenylalanine deaminase of Hordeum vulgare. J Biol Chem. 1961;236:2692-8.

34. Chen J, He L, Jiang Y, Wang Y, Joyce DC, Ji Z, Lu W. Role of phenylalanine ammonia-lyase in heat pretreatment-induced chilling tolerance in banana fruit. Physiol Plant. 2008;132: 318-28. http://dx.doi.org/10.1111/j.1399-3054.2007.01013.x

35. Okada T, Mikage M, Sekita S. Molecular characterization of the phenylalanine ammonia-lyase from Ephedra sinica. Biol Pharm Bull. 2008;31:2194-9.

http://dx.doi.org/10.1248/bpb.31.2194

36. Wen PF, Chen JY, Wan SB, Kong WF, Zhang P, Wang W, et al. Salicylic acid activates phenylalanine ammonia-lyase in grape berry in response to high temperature stress. Plant Growth Regul. 2008;55:1-10. http://dx.doi.org/10.1007/s10725-007-9250-7

37. Özden A. Probiotics are friendly bacteria useful for healthy life. Güncel Gastroenteroloji. 2003;7:22-38 (in Turkish).

38. Kang TS, Wang L, Sarkissian CN, Gámez A, Scriver CR, Stevens RC. Converting an injectable protein therapeutic into an oral form: phenylalanine ammonia lyase for phenylketonuria. Mol Genet Metab. 2010;99:4-9. http://dx.doi.org/10.1016/j.ymgme.2009.09.002

39. Gilbert HJ, Jack GW. The effect of proteinases on phenylalanine ammonia-lyase from the yeast Rhodotorula glutinis. Biochem J. 1981;199:715-23. http://dx.doi.org/10.1042/bj1990715

40. Guo J, Wang MH. Characterization of the phenylalanine ammonia-lyase gene (SIPAL5) from tomato (Solanum lycopersicum L.). Mol Biol Rep. 2009;36:1579-85. http://dx.doi.org/10.1007/s11033-008-9354-9

41. Sarma AD, Sharma R. Purification and characterization of UV-B induced phenylalanine ammonia-lyase from rice seedlings. Phytochemistry. 1999;50:729-37. http://dx.doi.org/10.1016/S0031-9422(98)00608-6

42. Reichert AI, He XZ, Dixon RA. Phenylalanine ammonia-lyase (PAL) from tobacco (Nicotiana tabacum): characterization of the four tobacco PAL genes and active heterotetrameric enzymes. Biochem J. 2009;424:233-42. http://dx.doi.org/10.1042/BJ20090620

43. Kalghatgi KK, Subba Rao PV. Microbial L-phenylalanine ammonia-lyase. Purification, subunit structure and kinetic properties of the enzyme from Rhizoctonia solani. Biochem J. 1995;149:65-72.

http://dx.doi.org/10.1042/bj1490065 